\title{
Araceae da Reserva Biológica da Represa do Grama - Descoberto, Minas Gerais, Brasil
}

\author{
Valquíria Rezende Almeida ${ }^{1}$, Livia Godinho Temponi ${ }^{2}$ \\ \& Rafaela Campostrini Forzza
}

\begin{abstract}
Resumo
(Araceae da Reserva Biológica da Represa do Grama - Descoberto, Minas Gerais, Brasil) A Reserva está localizada em Descoberto, Minas Gerais, e abrange uma área de 263,8 hectares de floresta estacional semidecídua. Foram encontrados oito gêneros e 17 espécies que ocorrem preferencialmente próximas dos cursos d'água e raramente formam grandes populações, sendo que a maioria das espécies está representada na área por poucos indivíduos. São apresentadas chave de identificação das espécies, descrições, informações sobre floração e frutificação, distribuição geográfica e habitat, e ilustrações.
\end{abstract}

Palavras-chave: Zona da Mata de Minas Gerais, taxonomia, floresta atlântica, flora.

\section{Abstract}

(Araceae of the Reserva Biológica da Represa do Grama - Descoberto, Minas Gerais, Brazil). The Reserva Biológica da Represa do Grama is situated in Descoberto, Minas Gerais, and consists of 263,8 hectares of seasonal forest. Eight genera and 17 species of Araceae have been recorded from the Reserve. The species occur commonly close to the river margins and rarely form large populations, the great majority of the species is represented by few individuals. A key for the identification of the species, descriptions, illustrations, information about flowering and fruiting, geographical distribution and habitats of each species are presented. Key-words: Zona da Mata of the Minas Gerais, taxonomy, atlantic forest, flora.

\section{INTRODUÇÃO}

Araceae compreende cerca de 106 gêneros e 2.823 espécies, que ocorrem naturalmente todos os continentes (Govaerts et al. 2002). Sua maior diversidade é verificada nas regiões tropicais, especialmente nas florestas úmidas (Mayo et al. 1997). O maior número de gêneros ocorre no Velho Mundo e apenas 10 são cosmopolitas. O continente ame-ricano é considerado o centro de diversidade da família, com cerca de 1500 espécies e 36 gêneros restritos (Croat 1979). No Brasil, são encontradas aproximadamente 400 espécies distribuídas em 36 gêneros (Mayo et al. 1997; Sakuragui 2000) sendo a floresta atlântica considerada o centro secundário de diversidade (Mayo 1990). Este trabalho apresenta as espé-cies de Araceae da Reserva Biológica da Re-presa do Grama, um dos poucos remanescentes de mata atlântica de Minas Gerais.

\section{Material e métodos}

A Reserva Biológica da Represa do Grama localiza-se na Zona da Mata de Minas Gerais, no município de Descoberto (21 $25^{\circ}$ 'S - 42 $56^{\prime} \mathrm{W}$ ), cerca de $100 \mathrm{~km}$ ao nordeste de Juiz de Fora, tendo sido a primeira Reserva Biológica criada no estado em 1971. Abrange uma área de 263,8 hectares de floresta estacional semidecídua e abriga seis nascentes que desembocam em dois córregos, dos quais ocorre captação de água para abastecimento parcial dos municípios de Descoberto e São João Nepomuceno. Para o desenvolvimento do presente estudo foram realizadas coletas entre agosto de 1999 a novembro de 2004 e as exsicatas foram incorporadas aos herbários CESJ, RB e SPF (siglas conforme Holmgren et al. 1990). As descrições e ilustrações foram elaboradas a partir dos materiais coletados na Reserva. A terminologia

\footnotetext{
Artigo recebido em 07/2005. Aceito para publicação em 11/2005.

${ }^{1}$ Departamento de Botânica, Universidade Federal de Juiz de Fora/Bolsista PIBIC/CNPq. Endereço atual: Mestranda do Museu Nacional/UFRJ.

${ }^{2}$ Doutoranda do Departamento de Botânica, Instituto de Biociências, Universidade de São Paulo.

${ }^{3}$ Jardim Botânico do Rio de Janeiro, Pacheco Leão 915, CEP 22460-030, Rio de Janeiro, RJ, Brasil. rafaela@jbrj.gov.br
} 
morfológica segue Madison (1977), Radford et al. (1979), Mayo (1991) e Mayo et al. (1997). São apresentadas chave de identificação das espécies, descrições, ilustrações, informações sobre floração e frutificação, distribuição geográfica e hábitats de ocorrência.

\section{Resultados E discussão}

$\mathrm{Na}$ Reserva Biológica da Represa do Grama, Araceae está representada por oito gêneros e 17 espécies que ocorrem preferencial-mente próximas dos cursos d'água e raramente formam grandes populações, sendo que a maioria das espécies está representada na área por poucos indivíduos. Este fato pode estar relacionado ao uso da floresta durante anos para o plantio de café e a extração de madeira, bem como a drástica fragmentação florestal que vem sofrendo a Zona da Mata de Minas Gerais ao longo dos últimos dois séculos.

Parte das espécies de Araceae encontradas na Reserva apresenta ampla distribui- ção geográfica (Anthurium pentaphyllum, A. scandens e Philodendron propinquum) e/ou são características de florestas estacionais semidecíduas (Asterostigma lombardii, Monstera adansonii, Philodendron speciosum, Heteropsis salicifolia). Porém, mesmo tratando-se de uma floresta estacional semidecídua, a flora da Reserva do Grama inclui espécies típicas da floresta ombrófila densa como Anthurium comtum, A. solitarium, Philodendron appendiculatum e $P$. curvilobum, sendo esta última observada pela primeira vez em Minas Gerais. A área também abriga espécies que ocorrem tanto em florestas semidecíduas quanto em floresta ombrófila densa como Philodendron hastatum e P. ornatum. Oliveira-Filho \& Fontes (2000) e Oliveira-Filho et al. (2005), demonstraram que as florestas estacionais semidecíduas, além de apresentarem um conjunto florístico próprio, abrigam também espécies da floresta ombrófila que toleram maior sazonalidade climática. As Araceae da Reserva do Grama sugerem que o observado por estes autores

\section{Chave para identifiearça espécies arbóreas ocorre também para} ervas.

1. Pecíolo não geniculado; espádice com zona estaminada, estaminada estéril e pistilada (heterogêneo).

2. Geófitas ou helófitas; lâmina membranácea, nervuras laterais secundárias reticuladas ou colocasióides.

3. Lâmina sectada; espata não constricta; espádice com zona estaminada vinácea; presença de estaminódios circundando a flor feminina, estigma astericiforme

6. Asterostigma lombardii

3'. Lâmina sagitada a ovado-sagitada; espata constricta; espádice com zona estaminada alva; ausência de estaminódios nas flores femininas, estigma globoso a papiloso.

4. Lâmina maior que $40 \mathrm{~cm}$ compr., verde nítido; bainha se estendendo até a metade do comprimento do pecíolo 17. Xanthosoma maximiliani

4'. Lâmina até $30 \mathrm{~cm}$ compr., verde-clara com nervuras vináceas e máculas alvas; bainha nunca atingindo a metade do comprimento do pecíolo .. 7. Caladium bicolor

2'. Hemi-epífita; lâmina cartácea a coriácea; nervuras laterais secundárias peniparalelinérvias.

5. Pecíolo alado; lâmina oval Philodendron propinquum

5'. Pecíolo não alado; lâmina sagitada.

6. Hemi-epífita arborescente; lâmina coriácea; espádice com zona estaminada quase igual ou mais curta que a zona estéril; estame pelo menos 3 vezes mais longo que largo; gineceu com mais de 15 lóculos 15. Philodendron speciosum

6'. Hemi-epífita herbácea; lâmina cartácea ou levemente cartácea; espádice com zona estaminada sempre mais longa que a zona estaminada estéril; estame menor que a razão 3:1; gineceu com até 10 lóculos. 
7. Pecíolo verrucoso; 9-11 pares de nervuras laterais primárias; nervuras interprimárias marcadamente visíveis na face adaxial; placentação axial, muitos óvulos por lóculo 13. Philodendron ornatum

7’. Pecíolo liso; 4-7 pares de nervuras laterais primárias; nervuras interprimárias ausentes, ou quando visíveis, apenas na face abaxial; placentação axial-basal; 2-5 óvulos por lóculo.

8. Espádice com zona estaminada estéril apical Philodendron appendiculatum

8'. Espádice com zona estaminada fértil até o ápice.

9. Lâmina maior que $50 \mathrm{~cm}$ compr., lobos posteriores retos, ápice cuspidado; pecíolo, nervura principal e espata esverdeadas com máculas vináceas esparsas 11. Philodendron curvilobum

9'. Lâmina até $40 \mathrm{~cm}$ compr., lobos posteriores abertos, ápice agudo; pecíolo, nervura principal e espata sem máculas vináceas ou avermelhadas

12. Philodendron hastatum

1'. Pecíolo geniculado; espádice não diferenciado em zonas (homogêneo).

10. Nervuras laterais secundárias paralelas às nervuras laterais primárias (peniparalelinérvias); estípete ca. $2 \mathrm{~cm}$ compr. 16. Rhodosphata latifolia

10'. Nervuras laterais secundárias reticuladas; estípete até $5 \mathrm{~mm}$ compr.

11. Perigônio presente.

12. Hemi-epífita; lâmina palmada; pedúnculo nunca atingindo a metade do comprimento do pecíolo 2. Anthurium pentaphyllum

12'. Epífita ou rupícola; lâmina inteira; pedúnculo igual ou maior que o comprimento do pecíolo.

13. Profilo persistente, envolvendo toda a extensão do caule, formando uma rede fibrosa; lâmina foliar menor que $12 \mathrm{~cm}$ de compr., com pontuações negras pelo menos na face abaxial; 2 óvulos por lóculo ....... 3. Anthurium scandens

13'. Profilo decíduo, se persistente desmanchando em fibras apenas no ápice do caule; lâmina foliar maior que $20 \mathrm{~cm}$ compr., sem pontuações negras; 1 óvulo por lóculo.

14. Lâmina coriácea com 8-10 pares de nervuras laterais primárias, nervuras interprimárias não evidentes; pedúnculo pêndulo; espata decurrente 4. Anthurium solitarium

14'. Lâmina cartácea a membranácea com mais de 20 pares de nervuras laterais primárias, nervuras interprimárias evidentes; pedúnculo ereto; espata não decurrente.

15. Lâmina discolor, verde-amarelada abaxialmente; bainha geralmente atingindo a metade do comprimento do pecíolo; espata freqüentemente decídua; espádice curto-espitado 1. Anthurium comtum

15'. Lâmina levemente discolor, nunca verde-amarelada abaxialmente; bainha até $2 \mathrm{~cm}$ compr.; espata persistente; espádice séssil

5. Anthurium sp.

11'. Perigônio ausente.

16. Caule com crescimento monopodial; pecíolo até $2 \mathrm{~cm}$; espádice curto-estipitado 8. Heteropsis salicifolia

16'. Caule com crescimento simpodial; pecíolo maior que $20 \mathrm{~cm}$ compr.; espádice séssil 
1. Anthurium comtum Schott, Bonplandia 10: 87.1862. Fig. $1 \mathrm{a}-\mathrm{b}$

Epífita. Caule ca. $1 \mathrm{~cm}$ diâm.; entrenó 2-6 mm; profilo não visto. Folha com pecíolo $6-13,5 \times 0,3-0,4 \mathrm{~cm}$, esverdeado, arredondado abaxialmente e aplanado ou canaliculado adaxialmente, geniculado apicalmente, genículo $0,5-1 \times 0,3-0,5 \mathrm{~cm}$, bainha geralmente atingindo a metade do comprimento do pecíolo, $3,8-4,5 \mathrm{~cm}$ compr., castanha, fibrosa; lâmina 28,3-48 × 4,6-7,4 $\mathrm{cm}$, verde discolor, verde-amarelada abaxialmente, lanceolada a oblanceolada, ápice agudo a acuminado, base cuneada, margem inteira, cartácea-membranácea; nervura central cilíndrica, levemente quilhada na região distal da face adaxial, nervuras laterais primárias mais de 20 pares, nervuras laterais primárias e interprimárias levemente salientes na face abaxial e impressas na adaxial, nervuras laterais secundárias reticuladas. Inflorescência 1 por axila foliar; pedúnculo $36,5-41 \times 0,2 \mathrm{~cm}$, verde, ereto; espata decídua, não vista; espádice homogêneo, curto-estipitado, ca. 10,2 $\times 0,2 \mathrm{~cm}$, roxo, estípete 3-4 × 2-4 mm. Flores monoclinas, homoclamídeas; tépalas-4, ca. 1,5 × 1,5 mm, roxas apicalmente, creme-esverdeadas com pontuações avermelhadas lateralmente, cuculadas, triangulares; estames ca. $1 \times 0,5$ $\mathrm{mm}$, anteras rimosas; gineceu ca. $9 \times 5 \mathrm{~mm}$, 2-locular, placentação axial-apical, 1 óvulo por lóculo, estigma fendido no centro, região estilar pouco mais larga que o ovário. Infrutescência imatura ca. $8,8 \times 0,5 \mathrm{~cm}$; pedúnculo $36-40 \times 0,2 \mathrm{~cm}$, verde, ereto. Frutos imaturos ca. $1,5 \times 1 \mathrm{~mm}$, castanho-claros, subprismáticos, tépalas persistentes.

Material examinado: 23.I.2001, fr., $R$. $C$. Forzza et al. 1750 (CESJ); 31.X.2001, fl. e fr., V. R. Almeida et al. 15 (CESJ).

Anthurium comtum possui raízes emaranhadas e numerosas folhas formando uma roseta, o que a distingue das demais espécies encontradas na Reserva. Esta espé-cie é exclusiva do Brasil, ocorrendo desde as matas do sul da Bahia até o Paraná (Coelho 2004).
Na Reserva, A. comtum é rara, ocorrendo somente no interior da mata em local úmido e sombreado.

2. Anthurium pentaphyllum (Aubl.) G. Don, Hort. Brit. 3: 633. 1839. Fig. $1 \mathrm{c}-\mathrm{d}$

Hemi-epífita. Caule 0,8-1,7 cm diâm.; entrenó ca. 1-2,3 cm; profilo 2,5-5,2 × 1,3 $\mathrm{cm}$, verde passando a castanho, desmanchando em fibras, bicarenado. Folha com pecíolo $29-54 \times 0,3 \mathrm{~cm}$, esverdeado, cilíndrico, levemente sulcado, geniculado apicalmente, genículo $0,7-1,5 \times 0,5-1 \mathrm{~cm}$; bainha 1,8-4,3 cm compr.; lâmina palmada, peciólulos $0,7-$ 2,2 cm compr., 7-11 segmentos 21-24,5 × 4,5-6 cm, verde discolor, oblanceolado, ápice acuminado a longo-acuminado, base cuneada às vezes assi-métrica, margem inteira a levemente ondulada, cartácea; nervura central levemente quilhada em ambas as faces, amareladas; nervuras laterais primárias 9-14 pares, nervuras laterais primárias e interprimárias levemente salientes em ambas as faces, nervuras laterais secundárias reticuladas. Inflorescência 1 por axila foliar; pedúnculo 3-7,5 ×0,3 cm, verde, ereto; espata 2,5-6 × 0,9-1,7 cm, não decurrente, não constricta, sem diferenciação entre lâmina e tubo, verde em ambas as faces, lanceolada, ápice agudo, reflexa, persistente; espádice homogêneo, séssil, $5,4-8,5 \times 0,4-0,8 \mathrm{~cm}$, verde à vináceo. Flores monoclinas, homoclamídeas; tépalas-4, ca. $2,5 \times 1 \mathrm{~cm}$, cuculadas, triangulares; estames ca. $2 \times 1 \mathrm{~mm}$, anteras rimosas; gineceu ca. 1,5 $\times 1 \mathrm{~mm}, 2$ locular, placentação axial-apical, 1 óvulo por lóculo, estigma fendido no centro, região estilar da mesma largura do ovário. Infrutescência ca. 9-10,5 $\times 2 \mathrm{~cm}$, pedúnculo 2,5-7,5 $\times 0,6 \mathrm{~cm}$, verde, ereto. Frutos ca. $6 \times$ $7 \mathrm{~mm}$., vináceos, cônicos, tépalas persistentes.

Material examinado: $26 . X I .2000$, fl., $R$. $C$. Forzza \& L .D. Meireles 1729 (CESJ); 10.II.2001, fl., R. M. Castro et al. 84 (CESJ); 8.VI.2001, fr., R. M. Castro 458 (CESJ); 5.X.2001, fr. A. V. Lopes \& V. R. Scalon 32 


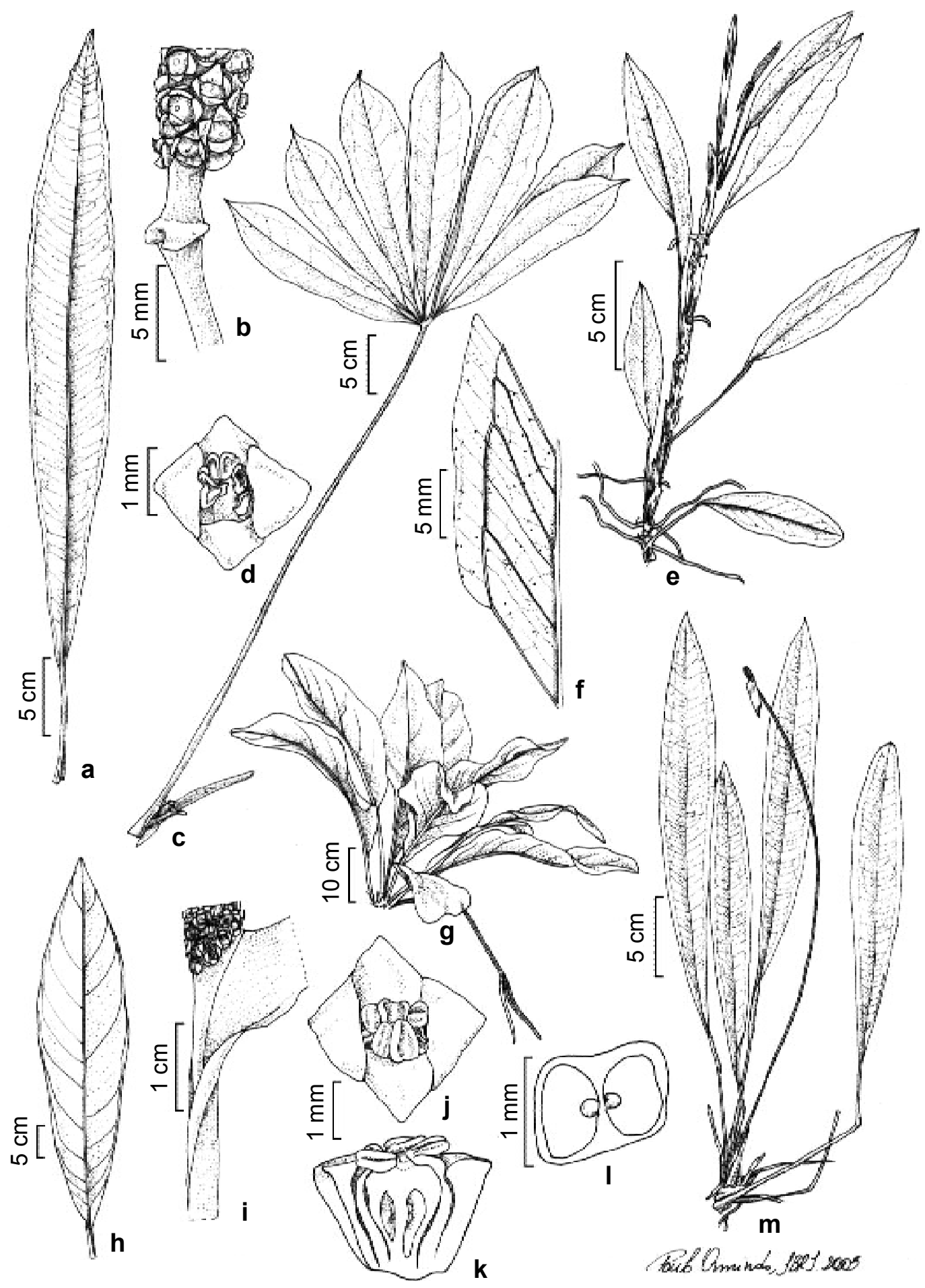

Figura 1 - a-b Anthurium comtum: a. pecíolo e lâmina evidenciando as nervuras laterais primárias; b. região proximal do espádice curto-estipitado. c-d $A$. pentaphyllum: c. pecíolo, lâmina e inflorescência; d. flor em vista frontal. e-f $A$. scandens: e. aspecto geral do ramo, evidenciando os profilos persistentes e inflorescência; $\mathrm{f}$. detalhe da lâmina foliar com pontuações glandulares e nervuras laterais secundárias reticuladas; g-l A. solitarium: g. hábito e inflorescência; h. lâmina evidenciando 8-10 pares de nervuras laterais primárias; i. espata decurrente; j. flor em vista frontal; k. flor em corte longitudinal; 1. ovário em corte transversal. m. Anthurium sp. hábito e parte da inflorescência. 
(CESJ); 12.I.2002, fl., V. R. Almeida et al. 33 (CESJ, RB); 8.III.2003, fl., V. R. Almeida et al. 35 (CESJ).

Anthurium pentaphyllum é facilmente distinguível das demais espécies ocorrentes na Reserva pela sua folha palmada (Fig. 1c) e pelas bagas, que quando maduras, são forte-mente vináceas. Trata-se de uma espécie am-plamente distribuída no Brasil, exceto na Região Centro-Oeste (Temponi 2001). Também ocorre no Peru, Colômbia, Guianas e Trinidad (Engler 1905). Na Reserva, é uma espécie muito freqüente ocorrendo na borda ou interior da mata.

3. Anthurium scandens (Aubl.) Engl., Fl. bras. 3(2): 78. 1878. Fig. 1 e-f

Epífita. Caule ca. 4 mm diâm.; entrenó 1,5-5,2 cm; profilo persistente, 4-5,4 ×0,7 $\mathrm{cm}$, castanho-claro, desmanchando em uma rede fibrosa. Folha com pecíolo 1,1-6,1 ×0,1 $\mathrm{cm}$, castanho-escuro, cilíndrico, levemente sulcado, geniculado apicalmente, genículo 2,5-5 × 1-2 mm; bainha ca. $3 \mathrm{~mm}$ compr.; lâmina 6,3-10,6 x 1,4-2,9 cm, verde discolor com pontuações negras em ambas as faces, lanceolada, ápice agudo, base cuneada, margem inteira, cartácea; nervura central levemente quilhada em ambas as faces, nervuras laterais primárias 6-11 pares, nervuras laterais primárias e interprimárias salientes na face abaxial e impressas na adaxial, nervuras laterais secundárias reticuladas. Inflorescência 1 por axila foliar; pedúnculo $3,5-4,7 \times 0,1 \mathrm{~cm}$, verde, ereto; espata ca. 1,2 $\times 0,4 \mathrm{~cm}$, não decurrente, não constricta, sem diferenciação entre lâmina e tubo, cremeesverdeada, lanceolada, ápice agudo, reflexa, persistente; espádice homogê-neo, curtoestipitado, ca. 1,7-2,2 × 0,3 cm, verde-claro, estípete ca. $1 \times 2 \mathrm{~mm}$. Flores monoclinas, homoclamídeas; tépalas-4, ca. $1 \times 1 \mathrm{~mm}$, verdes, cuculadas, triangulares; estames ca. $1 \times$ $0,5 \mathrm{~mm}$, anteras rimosas; gineceu ca. $1 \times 1$ mm, 2-locular, 2 óvulos por lóculo, placentação axial-apical, região estilar indiferenciada, estigma fendido no centro.
Infrutescência não vista.

Material examinado: 31.X.2001, fl., $V . R$. Almeida et al. 14 (CESJ).

Material adicional examinado. BRASIL. MINAS GERAIS, Marliéria, Parque Estadual do Rio Doce: 23.I.1997, fl., J. A. Lombardi 1535 (BHCB, RB); 24.III.2000, fl., L. G. Temponi et al. 88 (VIC); 14.XII.2000, fl. e fr., L. G. Temponi et al. 217 (VIC).

Característica muito marcante de Anthurium scandens é seu profilo persistente formando uma rede fibrosa que envolve completamente o caule (Fig. 1e). No Brasil ocorre nas Regiões Nordeste, Sudeste e Sul (Temponi 2001), além de apresentar ampla distribuição na América tropical (Engler 1905). Na Reserva, poucos indivíduos foram encontrados sempre no interior da mata e próximos a curso d'água.

4. Anthurium solitarium Schott, Prodr. Syst. Aroid.: 478. 1860. Fig. 1 g-1

Rupícola ou epífita. Caule ca. $2 \mathrm{~cm}$ diâm.; entrenó ca. 3 mm; profilo desmanchando em fibras. Folha com pecíolo $16-21 \times 1$ $\mathrm{cm}$, cas-tanho, arredondado abaxialmente e canalicu-lado adaxialmente, geniculado apicalmente, genículo $0,9 \times 0,9-1,1 \mathrm{~cm}$; bainha ca. 2,2 cm compr.; lâmina 48-100 × 10,6$41,5 \mathrm{~cm}$, verde levemente discolor, levemente elíptica a oblanceolada, ápice agudo, base levemente atenuada, margem inteira, fortemente coriácea; nervura central cilíndrica, fortemente proeminente na face abaxial, nervuras laterais primárias 8-10 pares, mais salientes na face abaxial, nervuras interprimárias ausentes, nervuras laterais secundárias reticuladas. Inflorescência 1 por axila foliar; pedúnculo $28-50 \times 0,3 \mathrm{~cm}$, verde, pêndulo; espata 5,8-29 × 1,2-3 cm, decurrente, não constricta, sem diferenciação entre lâmina e tubo, verde a castanha, lanceolada, ápice agudo, persistente; espádice homogêneo, séssil, 7,3-22,3 × 0,7 cm, vináceo a castanho. Flores monoclinas, homoclamídeas; tépalas-4, ca. 2-4 × 1,5-2 mm, cuculadas, triangulares; estames ca. 2,5 $\times 1$ 
$\mathrm{mm}$, anteras rimosas; gineceu ca. $2 \times 1 \mathrm{~mm}$, 2-locular, placentação axial, 1 óvulo por lóculo, estigma fendido no centro, região estilar mais larga que o ovário. Infrutescência não vista.

Material examinado: 31 .VIII.2001, fl., $V . R$. Almeida et al. 9 (CESJ, RB); 9.XII.2001, fl., V. R. Almeida et al. 30 (CESJ); 9.XII. 2001, fl., V. R. Almeida et al. 31 (CESJ).

Material adicional examinado. BRASIL. MINAS GERAIS: Muriaé, Floresta ciliar da área de captação de água do DEMAE, 21.III.1998, fl., A. Salino 4080 (BHCB, CESJ); Parque Nacional do Caparaó, 17.XII.1988, fl., L. Krieger s.n. (CESJ 23378, K). RIO DE JANEIRO: Parati, Ilha da Cotia, 22.XI.1989, fr., M. C. Marques 192 (RB); 19.XI.1992, bt., M. Nadruz et al. 809 (RB).

A presença de um longo e pêndulo pedúnculo, suportando um espádice também muito desenvolvido (Fig. 1g) constituem características marcantes de Anthurium solitarium. A espécie apresenta grande variação no tamanho da lâmina foliar, mas a venação é sempre muito proeminente. No Brasil, ocorre nos domínios da floresta atlântica da Bahia até o Rio de Janeiro. Além do Brasil, a espécie também é referida para a Bolívia e Paraguai (Engler 1905). Na Reserva, A. solitarium é uma espécie freqüente, ocorrendo como epífita ou rupícola sempre em locais abertos, próximos a curso d'água e na borda da mata.

\section{Anthurium sp. Fig. $1 \mathrm{~m}$}

Epífita. Caule ca. 6 mm diâm.; entrenó 0,8-1 cm; profilo 1,7-3,5 × 0,6-1 cm, verde passando a castanho, oval, ápice agudo, desmanchando em fibras no ápice do caule, carenado ou bicarenado. Folha com pecíolo $5-10,2 \times 0,2 \mathrm{~cm}$, verde, arredondado na face abaxial e sulcado na face adaxial, geniculado apicalmente, genículo 5-7 × 3-3,5 mm; bainha 1,5-2 cm compr.; lâmina 24-29,5 × 2,8$3,6 \mathrm{~cm}$, verde levemente discolor, lanceolada, ápice agudo, base longo-atenuada, margem inteira, cartácea; nervura central cilíndrica a levemente quilhada na porção distal de ambas as faces, nervuras laterais primárias mais de 20 pares, nervuras laterais primárias e interprimárias visíveis em ambas as faces, nervuras laterais secundárias reticuladas. Inflorescência 1 por axila foliar; pedúnculo ca. $35 \times 0,1 \mathrm{~cm}$, verde passando a marrom, ereto; espata ca. $2,4 \times 0,7 \mathrm{~cm}$, verde, lanceolada, ápice agudo, reflexa, persistente; espádice homogêneo, séssil. Flores monoclinas, homoclamídeas, tépalas-4, ca. 1 $\times 1 \mathrm{~mm}$, cuculadas, triangulares; estames ca. $2 \times 1 \mathrm{~mm}$, anteras rimosas; gineceu ca. $2 \times 1$ $\mathrm{mm}, 2$-locular, placentação axial, 1 óvulo por lóculo, estigma fendido no centro, região estilar um pouco mais larga que o ovário. Infrutescência não vista.

Material examinado: VI.2001, fl., R. $M$. Castro 539 (CESJ).

Durante a realização deste estudo, foi coletada uma única amostra de uma possível espécie nova de Anthurium. O espécime possui apenas a parte proximal de uma inflorescência o que inviabiliza sua descrição completa. A espécie é semelhante a Anthurium organense Engl. e Anthurium comtum, mas difere da primeira, principalmente, por apresentar lâmina foliar com base longo-atenuada e espádice séssil e de $A$. comtum pela lâmina foliar apenas levemente discolor, nunca amarelada na face abaxial, bainha curta, espata persistente e espádice séssil. A descrição desta nova espécie depende da coleta de novos espécimes, porém, mesmo com muitas tentativas, não foi possível reencontrar nenhum outro exemplar na localidade.

6. Asterostigma lombardii E. G. Gonç., Aroideana 22: 30-33. 1999. Fig. 2 a-d

Geófita. Raízes subterrâneas numerosas, delicadas, ca. $1 \mathrm{~mm}$ diâm. Caule tuberoso, branco internamente, com látex; entrenó inconspícuo; profilo ca. $50 \times 7 \mathrm{~cm}$, verde-claro a creme com estrias vináceas, marcescente. Folha com pecíolo $41-70 \times 2 \mathrm{~cm}$, verde com máculas vináceas a negras (rajado), cilíndrico, não geniculado apicalmente; bainha 3,9- 
5,5 cm compr.; lâmina $23-50 \times 20-38 \mathrm{~cm}$, verde, levemente discolor, pinada, membranácea; divisão anterior 18-28 × 17$32 \mathrm{~cm}, 3-6$ lobos laterais, 10,5-19,5 × 2-4,2 $\mathrm{cm}$, lanceolados, ápice longo-acuminado, base cuneada ou cuneada no lado acroscópico e decurrente no basioscópico, margem inteira; todas as nervuras impressas na face adaxial $\mathrm{e}$ salientes na abaxial, nervuras laterais primárias 7-9 pares, nervuras laterais secundárias reticuladas; divisões posteriores $8-20 \times 14,5-$ $26 \mathrm{~cm}$, porção acroscópica com 1 lobo e porção basioscópica com 2 a 4 lobos, porção desnuda das nervuras basais ca. 1,5 cm compr.; base, ápice, margem e número de nervuras similares aos da divisão anterior. Inflorescência 1 por axila foliar; pe-dúnculo $42-62 \times 1 \mathrm{~cm}$, concolor com o pecíolo, ereto; espata $10-16 \times 2,4-3,5 \mathrm{~cm}$, alva, vinácea na face interna da porção estaminada do espádice, não constricta, sem diferenciação em lâmina e tubo, lanceolada, ápice agudo, persis-tente; espádice heterogêneo, séssil, 8,5$12,5 \mathrm{~cm}$ compr.; zona estaminada $5-8 \times 0,4$ $\mathrm{cm}$, vinácea; zona pistilada $3,5-6 \times 0,5 \mathrm{~cm}$, creme esverdeada. Flores diclinas, aclamídeas; flor masculina em sinândrio, ca. $3 \times 2 \mathrm{~mm}$, vinácea, anteras com deiscência transversal; flor femi-nina ca. $2 \times 1,5 \mathrm{~mm}$, verde-clara, ovário globoso, 4-5 locular, 1 óvulo por lóculo, placentação axial, região estilar menor que o ovário, estigma estrelado, com 5 lobos agudos, amarelo-esverdeado, estaminódios unidos formando um sinândrio, róseos. Infrutescência: pedúnculo e espata como na inflorescência. Frutos imaturos, verde-amarelados, globosos, sulcados.

Material examinado: 26.XI.2000, fr., $R$. $C$. Forzza \& L. D. Meireles 1709 (CESJ, SPF); 3.XI.2002, fl., L. C. S. Assis et al. 615 (CESJ).

Asterostigma lombardii é facilmente reconhecida dentre as espécies da Reserva, por ser a única a apresentar lâmina sectada (Fig. 2a), pecíolo e pedúnculos com máculas formando rajas características, estigma estrelado e estaminódios unidos circundando o gineceu (Fig. 2 c-d). Esta espécie é semelhante a A. riedelianum (Schott) O. Kuntze, pelo fato de ambas possuírem estaminódios conatos em forma de uma urcéola naviforme, alongada no sentido do espádice (Gonçalves 1999, 2002). As duas espécies, no entanto, podem ser diferenciadas pela forma dos lobos do estigma. A. lombardii ocorre nas florestas semidecíduas do leste de Minas Gerais e Espírito Santo (Gonçalves 2002), enquanto $A$. riedelianum ocorre na Bahia. Na Reserva, são encontrados indivíduos esparsos de $A$. lombardii, preferencialmente em áreas constantemente alagadas.

7. Caladium bicolor (Aiton) Vent., Mag. Encycl. 4 (16): 464-471. 1801. Fig. 2e

Geófita. Caule tuberoso, globoso; entrenó inconspícuo; profilo 4-7 × 1,3-1,8 $\mathrm{cm}$, alvo a castanho, bicarenado, membranáceo. Folha com pecíolo 12,5-44 $\times$ $0,2-0,5 \mathrm{~cm}$, verde a castanho, levemente rajado, mais claro na face abaxial e lateralmente, cilíndrico, não genicu-lado apicalmente; bainha 7-12 cm compr.; lâmina 20-29 × 13,3-18,8 cm, verde discolor, com máculas alvas, ovado-sagitada, ápice acuminado, margem inteira, membranácea; divisão anterior 8,8-18,5 × 8,3-15,7 cm, nervura central cilíndrica, saliente em ambas as faces, nervuras laterais primárias 3-4 pares, levemente salientes e vináceas na face abaxial, aplanadas e fortemente vináceas na face adaxial, nervuras interprimárias pouco visíveis na face abaxial, nervuras laterais secundárias reticuladas; divisões posteriores 4,3$10,3 \times 3-9 \mathrm{~cm}$, nervuras acroscópicas $2-3$ por lado, nervura basioscópica 2 por lado, porção desnuda das nervuras basais ausente, nervura basal levemente quilhada. Inflorescência 1 por axila foliar; pedúnculo $15,5-30 \times 0,4 \mathrm{~cm}$, verde até castanho, ereto; espata $8,1-10,1 \mathrm{~cm}$ compr., constricta, com diferenciação entre lâmina e tubo, tubo $2,5-3 \times 6 \mathrm{~cm}$, lâmina $6-$ 7,5 $\times 5,5 \mathrm{~cm}$, creme-esverdeada, persistente; espádice heterogêneo, estipitado, 4,9-7,2 cm compr., alvo até creme, estípete ca. $3 \mathrm{~mm}$ compr., zona estaminada $3-4,1 \times 0,5-0,7 \mathrm{~cm}$, 




Figura 2 - a-d Asterostigma lombardii: a. lâmina e pecíolo; b. inflorescência; c. flor em vista frontal; d. sinândrio em vista longitudinal. e. Caladium bicolor: lâmina e inflorescência. f-g Heteropsis salicifolia: f. aspecto geral do ramo; g. região proximal do espádice curto-estipitado. h-i Monstera adansonii: h. lâmina fenestrada e pecíolo; i. flor monoclina. j-m Rhodospatha latifolia: j. lâmina e pecíolo; $\mathrm{k}$. inflorescência; 1 . espata; m região proximal do espádice estipitado. no Xanthosoma maximiliani: n. lâmina foliar e parte do pecíolo; o. detalhe das nervuras laterais secundárias colocasióides. 
zona estaminada estéril 0,8-1,7 ×0,3-0,5 cm, zona pistilada $0,9-1,3 \times 0,5-0,6 \mathrm{~cm}$. Flores diclinas, aclamídeas; flor masculina em sinândrio, estames $2-2,5 \times 2 \mathrm{~mm}$, anteras poricidas; flor masculina estéril ca. $1 \times 3 \mathrm{~mm}$; flor feminina ca. $2 \times 1 \mathrm{~mm}$, ovário 2-locular, placentação axial, 3-4 óvulos por lóculo, estigma globoso, região estilar da mesma largura do ovário. Infrutescência não vista.

Material examinado: $25 . \mathrm{XI} .2000$, fl., $R$. $C$. Forzza \& L. D. Meireles 1681(CESJ); 11.XI.2001, fl., V. R. Almeida et al. 25 (CESJ, $\mathrm{RB})$.

Caladium bicolor é facilmente reconhecida por apresentar lâmina foliar com máculas alvas, nervura central e região pró-xima a ela rósea até vermelha. Tais caracte-rísticas conferem à espécie um potencial orna-mental. É uma espécie amplamente distribuída, sendo encontrada do Amazonas até o Paraná (Mayo com. pess.), no entanto, este é o primeiro registro de $C$. bicolor em Minas Gerais. Na Reserva é uma das espécies sazonalmente dormentes, que forma apenas uma população próxima à margem do Ribeirão do Grama em local ensolarado e úmido.

8. Heteropsis salicifolia Kunth, Enum. Pl. 3: 60. 1841. Fig. $2 \mathrm{f}-\mathrm{g}$

Hemi-epífita. Caule monopodial, 2-4 $\mathrm{mm}$ diâm.; entrenó $2-4,5 \mathrm{~cm}$; profilo não visto. Folha com pecíolo ca. 4-7 $\times 1 \mathrm{~mm}$, castanho, cilíndrico, canaliculado, inteiramente genicu-lado; bainha envolvendo parcialmente o caule; lâmina $8-17,8 \times 2-6 \mathrm{~cm}$, verde levemente discolor, elíptico-oblonga a obovada, ápice acu-minado, base cuneada, margem inteira, cartá-cea; nervura central saliente na face abaxial e levemente sulcada na adaxial, nervuras laterais primárias mais de 15 pares; nervuras laterais primárias e interprimárias pouco visíveis na face adaxial, levemente salientes na face abaxial, nervuras laterais secundárias reticuladas. Inflorescência em pré-antese; pedúnculo ca. $5 \times 1 \mathrm{~mm}$ compr., castanho, ereto; espata ca. $2 \mathrm{~cm}$ compr., creme, decídua após a antese; espádice homogêneo, curto-estipitado, estípete ca. $3 \times 2 \mathrm{~mm}$ compr. Flores monoclinas, aclamídeas, dispostas de 7-9 fileiras em espiral, 4-5 por espiral. Infrutescência 2,5-3,3 × 1-1,2 cm, pedúnculo ca. $1,1-1,3 \times 0,1 \mathrm{~cm}$, verde passando a marrom, ereto. Frutos imaturos 6-8 mm diâm., verdes, subprismáticos.

Material examinado: 26.IX.2000, fr., $R$. $C$. Forzza \& L. D. Meireles 1697 (CESJ); 7.III.2004, bt., R. C. Forzza et al. 2981 (CESJ, $\mathrm{K}, \mathrm{RB})$.

Material adicional examinado. BRASIL. MINAS GERAIS: Marliéria, Parque Estadual do Rio Doce, 24.III.2000, fl., L. G. Temponi et al. 102 (VIC); 7.IV.2000, fr., L. G. Temponi et al. 110 (VIC).

Heteropsis salicifolia distingue-se das demais espécies ocorrentes na Reserva, por ser a única hemi-epífita com crescimento monopodial e pelo pecíolo muito curto (até 2 cm compr.) (Fig. 2f). A espécie ocorre nos estados de Pernambuco, Bahia, Rio de Janeiro, São Paulo, Minas Gerais e Paraná. Muito rara na Reserva, podendo ser encontrada somente no interior da mata em locais bem sombreados.

9. Monstera adansonii Schott, Wien. Zeitschr. 4: 1028. 1830. Fig. 2 h-i

Hemi-epífita. Caule simpodial, ca. $1 \mathrm{~cm}$ diâm.; entrenó ca. $3 \mathrm{~cm}$; profilo não visto. Folha com pecíolo $21-42 \times 0,5-1 \mathrm{~cm}$, esverdeado, fortemente canaliculado, apicalmente genicu-lado, genículo 1,5-2 cm compr.; bainha esten-dendo-se até o genículo; lâmina 31-51 × 18,5-29 cm, verde levemente discolor, elíptico-oval, fenestrada ou não, ápice acuminado, base ate-nuada, margem inteira, coriácea; nervura central quilhada na porção proximal da face abaxial e aplanada na face adaxial, 9-16 pares de nervu-ras laterais primárias, levemente salientes, visí-veis em ambas as faces, nervuras interprimá-rias pouco visíveis, nervuras laterais secundá-rias reticuladas. Inflorescência 1 por axila fo-liar; pedúnculo $10,5-20 \times 0,5 \mathrm{~cm}$, verde, ereto; 
espata 11-17 cm compr., não constricta, sem diferenciação entre lâmina e tubo, elíptica, ápice cuspidado, decídua após a antese; espádice homogêneo, séssil, 7,5-11,5 × 1,5 $\mathrm{cm}$, creme. Flores monoclinas, aclamídeas; estames ca. $3 \times 1 \mathrm{~mm}$; gineceu ca. $3 \mathrm{~mm}$ compr., prismático, ovário 2-locular, 2 óvulos por lóculo, região estilar mais larga que o ovário, estigma fendido no centro, alaranjado. Infrutescência imatura $10-17 \times 2-2,5 \mathrm{~cm}$, alva; pedúnculo $16-20 \times 0,5 \mathrm{~cm}$, verde, ereto. Frutos 1,5-1,8 × 0,7 cm, verde-amarelados, subprismáticos.

Material examinado: 2 .II.2000, fl., P. C. L. Faria et al. s.n. (CESJ 31035); 26.XI.2000, fr., R. C. Forzza \& L. D. Meireles 1696 (CESJ, SPF); 21.IV.2001, fl., R. M. Castro et al. 273 (CESJ); 31.X.2001, fr., V. R. Almeida et al. 12 (CESJ, RB); 20.IV.2002, fl., R. C. Forzza et al. 2181 (CESJ).

Monstera adansonii apresenta como características marcantes a lâmina foliar adulta fenestrada, pecíolo longo com mais de $20 \mathrm{~cm}$ de comprimento, fortemente canaliculado com alas persistentes e bainha longa até o genículo (Fig. 2h). Esta espécie é amplamente distri-buída no Brasil, ocorrendo em todas as regiões (Temponi 2001). É também registrada para Venezuela, Guianas e Peru (Madison 1977). Na Reserva é amplamente distribuída pelo interior da mata sendo uma das espécies mais freqüentes de Araceae.

10. Philodendron appendiculatum Nadruz \& Mayo, Bol. Bot. Univ. São Paulo 17: 50. 1998. Fig. $3 \mathrm{a}$

Hemi-epífita. Caule 0,7-1 cm diâm.; entrenó 2-3,4 cm; profilo 7-19 × 1-2 cm, alvo-esverdeado a castanho escuro, elíptico a lanceolado, ápice agudo a arredondado, carenado ou bicarenado, membranáceo. Folha com pecíolo 22,5-28,2 ×0,3-0,4 cm, verde, cilíndrico, liso, não geniculado apicalmente; bainha 2,3-4,2 cm compr.; lâmina 35,7-39,6 × $12-15 \mathrm{~cm}$, verde levemente discolor, sagitada, ápice acuminado, margem inteira, cartácea; divisão anterior $27-29,5 \times 8,3-13,3 \mathrm{~cm}$, nervura central saliente, levemente arredondada na face abaxial, aplanada na face adaxial, nervuras laterais primárias 4-(5) pares, mais visíveis na face abaxial, aplanadas; nervuras interprimárias visíveis na face abaxial; nervuras secundárias peniparalelinérvias; divisões posteriores $8,7-10,1 \times 4,8-6,9 \mathrm{~cm}$, nervuras acroscópicas 2 por lado, nervuras basioscópicas 1-2 por lado, porção desnuda das nervuras basais $1,3-2,5 \mathrm{~cm}$. Inflorescência 1 por axila foliar; pedúnculo ca. 2,3-3,2 $\times 0,3$ cm, verde, ereto; espata ca. 7,2-7,9 cm compr., constricta, com diferencia-ção entre lâmina e tubo, tubo ca. $3 \times 2,3 \mathrm{~cm}$, lâmina ca. 4,3-5 $\times$ $2,3 \mathrm{~cm}$, lâmina e tubo alvos sendo o tubo pouco esverdeado na face externa; espádice heterogêneo, curto-estipitado, ca. 8-8,3 cm compr., estípete ca. $3 \mathrm{~mm}$ compr., zona estaminada ca. $3 \times 0,4 \mathrm{~cm}$; zona estaminada estéril ca. $1 \times 0,7 \mathrm{~cm}$; zona estaminada estéril apical 1,9 × 0,6 cm; zona pistilada ca. 2,2 $\times$ $0,7 \mathrm{~cm}$. Flores diclinas, aclamídeas; flor masculina: estames ca. $1,5 \times 1 \mathrm{~mm}$, anteras rimosas; estaminódios apicais ca. $2 \times 1 \mathrm{~mm}$; flor masculina estéril 2-3 × 1-2 mm; flor feminina ca. $2 \times 1 \mathrm{~mm}$, ovário 7-8-locular, placentação axial-basal, 3-(4) óvulos por lóculo, região estilar pouco mais larga que o ovário, estigma discóide. Infrutescência não vista.

Material examinado: 31.X.2001, fl., $V$. $R$. Almeida et al. 13 (CESJ, RB); 26.XI.2004, fl., C. Sakuragui 1640 (RB).

Nadruz \& Mayo (1998) descreveram Philodendron appendiculatum como semelhante a $P$. inops Schott, diferindo desta pela forma da lâmina foliar e pelo forte estrangulamento na porção mediana do espádice e da espata (Fig. 3a). Seu nome deriva da presença de uma porção de flores estaminadas estéreis no ápice do espádice, que constitui uma característica marcante na espécie (Fig. 3a). Tem ocorrência registrada nos estados da Região Sudeste, Paraná e Santa Catarina (Coelho 2000). Na Reserva é pouco freqüente sendo restrita a locais úmidos e sombreados. 
11. Philodendron curvilobum Schott, Syn. Aroid. 102. 1856. Fig. 3b

Hemi-epífita. Caule ca. $2 \mathrm{~cm}$ diâm.; entrenó 1,5-2 cm; profilo $15,5-34,8 \times 2,3-$ $2,7 \mathrm{~cm}$, alvo-esverdeado a castanho escuro, com poucas máculas vináceas, lanceolado, ápice agudo, carenado ou bicarenado, membranáceo. Folha com pecíolo 39-60 × 0,8 $\mathrm{cm}$, esverdeado com máculas vináceas esparsas, levemente arredondado na face abaxial e aplanado na adaxial, liso, não geniculado apicalmente; bainha ca. $6,5 \mathrm{~cm}$ compr.; lâmina 58-60 × 18,5-31 cm, verde levemente discolor, sagi-tada, ápice acuminado, margem inteira, cartácea; divisão anterior 43-44,5 × 15-28 cm, nervura central saliente na face abaxial sendo levemente quilhada na porção proximal, aplanada na face adaxial, nervuras laterais primárias 6-7 pares, levemente salientes e visíveis em ambas as faces, aplanadas, nervuras interprimárias pouco visíveis, nervuras laterais secundárias peniparalelinérvias; divisões posteriores 14 $15,5 \times 8,4-10 \mathrm{~cm}$, nervuras acroscópicas 2 por lado, nervura basioscópica 1-2 por lado, porção desnuda das nervuras basais ca. $2 \mathrm{~cm}$. Inflorescência 1-2 por axila foliar; pedúnculo $6,5-11,2 \times 0,5 \mathrm{~cm}$, verde, ereto; espata 11,5 $17,2 \mathrm{~cm}$ compr., constricta, com diferenciação entre lâmina e tubo, verde com máculas vináceas na face externa e lâmina alva e tubo com máculas ver-melhas na face interna, tubo 5,5-8 × 3-5 cm, lâmina 6,2-9 × 2,6-4,6 cm, espádice hetero-gêneo, séssil, ca. $11,5 \mathrm{~cm}$ compr.; zona esta-minada ca. $5,9 \times 1,2 \mathrm{~cm}$; zona estaminada es-téril ca. $1,9 \times 1,5 \mathrm{~cm}$; zona pistilada 4,3-6 × 1,5 cm. Flores diclinas, aclamídeas; flor mascu-lina: estames ca. $3 \times$ $1 \mathrm{~mm}$, anteras rimosas; flor masculina estéril 2,5-3 $\times 2-2,5 \mathrm{~mm}$, castanho-escura; flor feminina 3-4 × 1,5-2 mm, ovário 7-8-locular, placentação axial-basal, 3-5 óvulos por lóculo, estigma papiloso, região estilar da mesma largura do ovário. Infru-tescência ca. $10 \times 2,5 \mathrm{~cm}$, pedúnculo $10-10,5 \times 0,5 \mathrm{~cm}$, verde, ereto. Frutos verde-claros, sementes amarelas a alaranjadas.
Material examinado: 26.XI.2000, fl., $R$. $C$. Forzza \& L. D. Meireles 1698 (CESJ, SPF); 24.I.2001, fr., R. C. Forzza et al. 1768 (CESJ, SPF); 10.XI. 2001, fl., V. R. Almeida et al. 19 (CESJ).

Philodendron curvilobum apresenta lâmina foliar sagitada com os lobos posteriores retos (Fig. 3b) e pecíolo, nervura central e espata esverdeados com máculas avermelhadas. Tais características são marcantes e distingue esta espécie das demais do gênero, incluindo $P$. hastatum, uma espécie muito semelhante e que também ocorre na Reserva. $P$. curvilobum foi citado anteriormente apenas para os estados do Rio de Janeiro e São Paulo (Sakuragui 1998) sendo este seu primeiro registro para Minas Gerais. É uma das espécies mais comuns na área, formando grandes populações próximas a cursos d'água no interior e na borda da mata.

12. Philodendron hastatum K. Koch \& Sellow, Index Sem. 7. 1854. Fig. 3 c-d

Hemi-epífita. Caule ca. $1 \mathrm{~cm}$ diâm.; entrenó ca. $6 \mathrm{~cm}$; profilo 7-20,5 × 2-2,5 cm, alvo a castanho-claro, elíptico a lanceolado, ápice agudo, carenado a bicarenado, membranáceo a paleáceo. Folha com pecíolo 23,5$34 \times 0,5 \mathrm{~cm}$, verde, cilíndrico, liso, ápice não geniculado; bainha 5,1-6,2 cm compr.; lâmina $25,5-38,3 \times 6,3-14 \mathrm{~cm}$, verde levemente dis-color, sagitada a hastada, ápice agudo, margem inteira, levemente cartácea; divisão anterior $21-37,5 \times 7,1-14,5 \mathrm{~cm}$, nervura central apla-nada, levemente arredondada na face abaxial, nervuras laterais primárias 4-5 pares, aplana-das na face adaxial, levemente salientes na face abaxial, visíveis em ambas as faces, ner-vuras interprimárias ausentes ou pouco visíveis e às vezes visíveis na face abaxial, nervuras laterais secundárias peniparaleli-nérvias; divisões posteriores 7,2$8,3 \times 4,1-5,7 \mathrm{~cm}$, nervuras acroscópicas $2-3$ por lado, nervuras basioscópicas 1 por lado, porção desnuda das nervuras basais 1,7-2,5 $\mathrm{cm}$. Inflorescência $2-3$ por axila foliar; pedúnculo 3,5-5,5 × 0,3-0,4 cm, verde, ereto; 


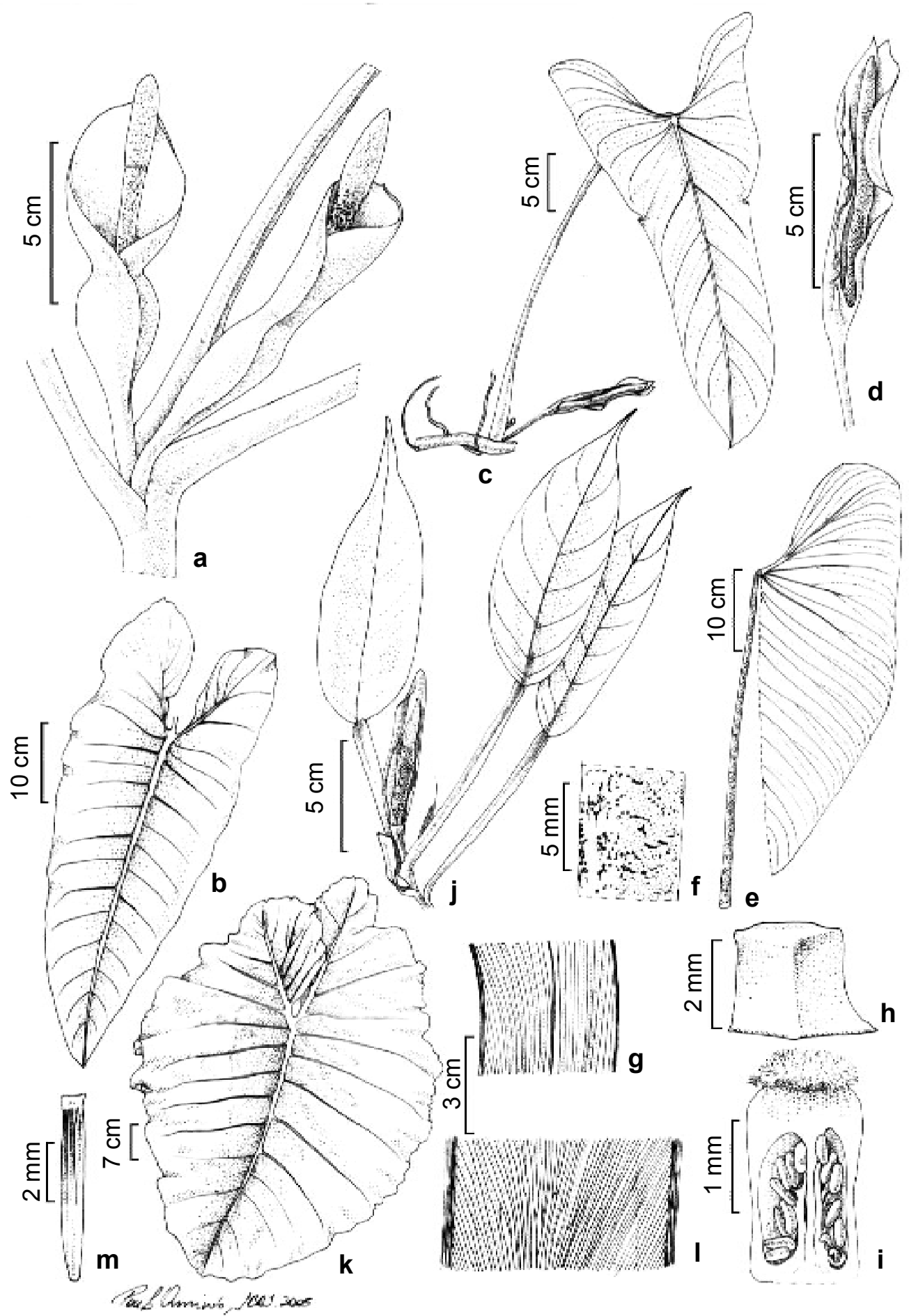

Figura 3 - a Philodendron appendiculatum: inflorescência evidenciando a forte constrição da espata e a porção estéril no ápice do espádice. b. P. curvilobum: lâmina foliar evidenciando os lobos posteriores retos. c-d P. hastatum: c. lâmina foliar evidenciando os lobos posteriores abertos. d. inflorescência com parte da espata seccionada. e-i P. ornatum: e. parte da lâmina foliar e pecíolo verrucoso; f. detalhe da ornamentação do pecíolo; g. nervuras laterais primárias com uma interprimária marcadamente visível.; h flor masculina estéril; i. flor feminina em corte longitudinal, evidenciando grande número de óvulos. j. P. propinquum: aspecto geral do ramo e inflorescência com parte da espata seccionada. k$\mathrm{m}$ P. speciosum: $\mathrm{k}$. lâmina; 1 . detalhe de nervuras laterais primárias sem interprimária marcadamente visível; $\mathrm{m}$. estame. 
espata 8-13,5 cm compr., constricta, com diferenciação entre lâmina e tubo, tubo 3-3,5 × $4,5 \mathrm{~cm}$, creme, lâmina $3,5-8,5 \times 3-4,5 \mathrm{~cm}$, alva; espádice heterogêneo, estipitado, 7-10 cm compr., estípete ca. $5 \mathrm{~mm}$ compr.; zona estaminada ca. 4,5 ×0,7 cm, zona estaminada estéril ca. $7 \times 8 \mathrm{~mm}$, zona pistilada $4,2-4,5 \times$ 0,8-1 cm. Flores diclinas, aclamí-deas; flor masculina: estames ca. 1,5 × $1 \mathrm{~mm}$, anteras rimosas; flor masculina estéril ca. $2 \times 1 \mathrm{~mm}$; flor feminina ca. $2 \times 1 \mathrm{~mm}$, ovário 7-9locular, placentação axial-basal, 2-3(4) óvulos por lóculo, estigma globoso, região estilar pouco mais larga que o ovário. Infrutescência não vista.

Material examinado: 26.XI.2000, fl., R. C. Forzza \& L. D. Meireles 1699 (CESJ, SPF); 31.VIII.2001, fl., V. R. Almeida et al. 10 (CESJ, RB).

Philodendron hastatum é muito semelhante a $P$. curvilobum (vide comentário anterior). No Brasil, a espécie encontra-se distribuída nas matas de Minas Gerais e Rio de Janeiro (Sakuragui 1998). Na Reserva esta espécie é freqüente nos locais úmidos próximos dos cursos d'água.

13. Philodendron ornatum Schott, Oesterr. Bot. Wochenbl. 3: 378. 1853. Fig. 3 e-i

Hemi-epífita. Caule 4-4,5 cm diâm., entrenó 1-3,5 cm; profilo ca. $18 \mathrm{~cm}$ compr., verde-rosado externamente e alvo internamente, fibroso. Folha com pecíolo 50-60×1 $\mathrm{cm}$, verde, castanho próximo ao limbo, com verrugas mais claras em toda a sua extensão, aplanado a levemente côncavo na face adaxial e arredondado na abaxial, ápice geniculado apicalmente, genículo ca. $3,5 \times 0,6 \mathrm{~cm}$, bainha 2,9-3,2 cm compr.; lâmina 46-53 × 34$36 \mathrm{~cm}$, verde discolor, sagitada, ápice agudo, margem inteira, levemente cartácea; divisão anterior 33-40 × 34-36 cm, nervura central aplanada e verde na face abaxial, proeminente e vinácea na porção proximal da face adaxial, nervuras laterais primárias 9-11 pares, salientes na face abaxial, levemente avermelhadas, nervuras interprimárias marcadamente visíveis na face abaxial, nervuras laterais secundárias peniparalelinérvias; divisões posteriores $12,5-16 \times 13 \mathrm{~cm}$, nervuras acroscópicas 2-3 por lado, nervuras basioscópicas 3-4 por lado, porção desnuda das nervuras basais ca. $3 \mathrm{~cm}$. Inflorescência 2 por axila foliar; pedúnculo 5,5-7 $\times 1 \mathrm{~cm}$, verde a castanho, ereto; espata 12,5-16 cm compr., levemente constricta, sem forte diferenciação entre lâmina e tubo, verde-amarelada com estrias vináceas na face externa e alva na face interna; espádice heterogêneo, estipitado, 10,5-12 cm compr., estípete ca. $1 \mathrm{~cm}$; zona estaminada 5-6 × 1,3 cm, alva; zona estaminada estéril ca. $2,5 \times$ $1,5 \mathrm{~cm}$, alva; zona pistilada $3-3,3 \times 1,3 \mathrm{~cm}$, verde. Flores diclinas, aclamídeas; flor masculina: estames ca. $2 \times 1,5 \mathrm{~mm}$, anteras rimosas; flor masculina estéril ca. $2 \times 1,5 \mathrm{~mm}$; flor feminina ca. $2 \times 1 \mathrm{~mm}$, ovário 3-5 locular, muitos óvulos por lóculo, placentação axial, região estilar da mesma largura ou pouco menor que a do ovário, estigma globoso. Infrutescência não vista.

Material examinado: 12.I.2002, fl., $V . R$. Almeida et al. 32 (CESJ).

Philodendron ornatum é facilmente distinguível das demais espécies da Reserva por apresentar um pecíolo verrucoso, nervuras interprimárias muito visíveis adaxialmente e muitos óvulos por lóculo (Fig. 3 e-i). A espécie já foi registrada para as Regiões Norte, Nordeste e Sudeste do Brasil, ocorrendo em floresta pluvial atlântica baixo-montana, de encosta, matas de restinga e floresta amazônica em locais úmidos e sombreados podendo chegar a $1.100 \mathrm{~m}$ de altitude (Coelho 1995). Na Reserva, só foram encontrados dois indivíduos, em local sombreado próximo de curso d'água.

14. Philodendron propinquum Schott, Syn. Aroid.:78.1856. Fig. 3j

Hemi-epífita. Caule 3-4 mm diâm.; entrenó 0,6-3,4 cm; profilo ca. $6,2 \times 0,7 \mathrm{~cm}$, castanho-claro, oblongo-lanceolado, ápice arredondado, bicarenado, levemente cartáceo. 
Folha com pecíolo 7,7-12 × 0,1 cm, verdeclaro, cilíndrico, liso, não geniculado apicalmente; bainha estendendo-se por todo comprimento do pecíolo, formando alas, verde-clara; lâmina 10,1-16,3 × 3,2-5 cm, verdes discolores com nervuras da face abaxial amarelo-claras, oval, ápice acuminado, base cuneada-oblíqua, margem inteira, membranácea; nervura central impressa na face adaxial, arredondada e fortemente proeminente na porção proximal da face abaxial, nervuras laterais primárias 5-7 pares, pouco visíveis na face adaxial, salientes na face abaxial, nervuras interprimárias ausentes, nervuras laterais secundárias peniparalelinérvias. Inflorescência 1 por axila foliar; pedúnculo 1,4-1,8 $\times 0,2 \mathrm{~cm}$, verde, ereto; espata $6,5-7,7 \mathrm{~cm}$ compr., constricta, com leve diferenciação entre lâmina e tubo; espádice heterogêneo, estipitado, 6,3-7,3 × $0,5-0,7 \mathrm{~cm}$, estípete $0,7-1,3 \mathrm{~cm}$ compr.; zona estaminada $2,5-3,4 \times 0,4-0,7 \mathrm{~cm}$, zona estaminada estéril ca. $5 \times 7 \mathrm{~mm}$, zona pistilada $2,2-3,4 \times 0,6-0,7 \mathrm{~cm}$. Flores diclinas, aclamídeas; flor masculina: estames ca. 1,5 $\times$ $1 \mathrm{~mm}$, antera rimosas; flor masculina estéril ca. $1 \times 1,5 \mathrm{~mm}$; flor feminina ca. $1 \times 1,5 \mathrm{~mm}$, ovário 3-locular, muitos óvulos por lóculo, placentação axial, região estilar da mesma largura do ovário, estigma papiloso. Infrutescência não vista.

Material examinado: 26.XI.2004, fl., $C$. Sakuragui 1638 (RB).

Philodendron propinquum tem como característica marcante a presença de bainha estendendo-se por todo comprimento do pecíolo (Fig. 3j), tal característica não é encontrada em nenhuma outra espécie do gênero ocorrente na Reserva. A espécies tem ocorrência registrada para os estados do Espírito Santo, Minas Gerais, Paraná e Rio de Janeiro. Na Reserva, não é muito freqüente, estando restrita a locais mais úmidos e sombreados.

15. Philodendron speciosum Schott ex Endl., Gen. Pl. 1(3): 237. 1837. Fig. 3 k-m
Hemi-epífita. Caule espesso, ca. $10 \mathrm{~cm}$ diâm.; entrenó 2,1-5,5 cm; profilo não visto. Folha com pecíolo ca. $110 \times 2 \mathrm{~cm}$, verde, cilíndrico, liso, ápice não geniculado; bainha ca. $15 \mathrm{~cm}$ compr.; lâmina ca. $100 \times 70 \mathrm{~cm}$, verdes discolores com nervuras da face abaxial vináceas, sagitada, ápice agudo, margem inteira a levemente ondulada, coriácea; divisão anterior ca. $74 \times 70 \mathrm{~cm}$, nervura central apla-nada na face abaxial e arredondada na adaxial, nervuras laterais primárias 6-8 pares, salientes em ambas as faces, nervuras interprimárias ausentes, nervuras laterais secundárias peniparalelinérvias; divisões posteriores ca. $26 \times 29 \mathrm{~cm}$, nervuras acroscópicas 3-4 por lado, nervuras basioscópicas 4-5 por lado, nervura basal quilhada na face adaxial, porção desnuda das nervuras basais ca. 3,5 $\mathrm{cm}$. Inflorescência 1 por axila foliar; pedúnculo 13-15 × 1,2-1,7 cm, verde, ereto; espata 26-39 cm compr., constricta, com leve diferenciação entre lâmina e tubo, verde-clara na base e vermelha no ápice da face externa, atro-vinácea na face interna; espádice heterogêneo, estipitado, ca. $30 \mathrm{~cm}$ compr., estípete $2-4 \mathrm{~cm}$ compr.; zona estaminada ca. $10 \times 2 \mathrm{~cm}$, creme-esbranqui-çada, zona estaminada estéril ca. $12 \times 2-3 \mathrm{~cm}$, cremeesbranquiçada e zona pistilada $5-6 \times 2,3 \mathrm{~cm}$, amarelada,. Flores diclinas, aclamídeas; flor masculina: estames 6-7 $\times 1 \mathrm{~mm}$, anteras rimosas; flor masculina estéril 5-6 $\times 2 \mathrm{~mm}$; flor feminina ca. $6 \times 4 \mathrm{~mm}$, ovário 16-(20)locular, 3 óvulos por lóculo, placentação axialbasal, região estilar da mesma largura do ovário, estigma papiloso. Infrutescência não vista.

Material examinado: $10 . \mathrm{XI} .2001$, fl., $V . R$. Almeida et al. 18 (CESJ).

Philodendron speciosum trata-se da espécie de maior porte dentre as Araceae encontradas na Reserva. Caracteriza-se por ser uma hemi-epífita com caule muito robusto e com um grande número de cicatrizes foliares, zona estaminada estéril de tamanho equivalente ou mais longa que a zona estaminada fértil e estames pelo menos três vezes mais 
longos que largos (Fig. 3m). P. speciosum é uma espécie restrita ao sudeste brasileiro e na Reserva, foi encontrado somente dois indivíduos no dossel da mata de galeria.

16. Rhodospatha latifolia Poepp., Nov. Gen. Sp. P1. 3: 91. 1845. Fig. 2 j-m

Hemi-epífita. Entrenó 0,8-1,5 cm; profilo $2,2-27 \times 1,2-1,4 \mathrm{~cm}$, alvo internamente e verde-claro externamente, oval a lanceolado, ápice arredondado a agudo, carenado ou bicarenado, membranáceo passando a coriáceo. Folha com pecíolo 34-47 $\times$ $0,5 \mathrm{~cm}$, verde-claro, arredondado na face abaxial e levemente canaliculado na adaxial, apicalmente geniculado, genículo 2,3-2,8 $\times$ $0,4 \mathrm{~cm}$; bainha até o genículo; lâmina 31-45,5 $\times 15,1-19,5 \mathrm{~cm}$, verde, levemente discolor, elíptica a oblonga, ápice acuminado, base arredondada, margem inteira, cartácea; nervura central arredondada e fortemente proeminente na face abaxial, sulcada na face adaxial, nervuras laterais primárias mais de 20 pares, salientes na face abaxial e visíveis em ambas as faces, nervuras interprimárias às vezes visíveis; nervuras laterais secundárias peniparalelinérvias. Inflorescência 1 por axila foliar; pedúnculo $14-16 \times 0,5 \mathrm{~cm}$, verdeclaro, ereto; espata $17,1 \times 8,4 \mathrm{~cm}$, não constricta, sem diferenciação entre lâmina e tubo, alva na face interna e verde-clara na face externa, elíptica, ápice agudo, decídua após a antese; espádice homogêneo, estipitado, 14,3$17,2 \times 1,2 \mathrm{~cm}$, rosado, estípete 1,4-2,2 cm compr. Flores monoclinas, aclamídeas; estames 3,5-4 × 0,5-1 mm, livres, anteras rimosas; gineceu ca. $4 \times 2 \mathrm{~mm}$, prismático, ovário 2-locular, muitos óvulos por lóculo, placentação axial, região estilar da mesma largura do ovário, estigma fendido no centro. Infrutescência imatura, ca. $21 \times 1,3 \mathrm{~cm}$, pedúnculo ereto. Frutos imaturos verdes.

Material examinado: 10.XI.2001, fl. e fr., V. R. Almeida et al. 17 (CESJ); 9.XII.2001, fl., V. R. Almeida et al. 29 (CESJ).

Rhodospatha latifolia distingue-se das demais espécies encontradas na Reserva por apresentar lâminas foliares com um padrão de venação peniparalelinérvio muito característico, espádice rosado e estípete bem desenvolvido (ca. $2 \mathrm{~cm}$ compr.) (Fig. $2 \mathrm{~m}$ ). É uma espécie comum em matas da Paraíba, sul da Bahia, Espírito Santo e Minas Gerais (Temponi 2001). Na Reserva é freqüente em locais sombreados ou iluminados, sempre próxima a curso d'água.

17. Xanthosoma maximiliani Schott, Bonplandia 10: 322. 1882. Fig. 2 n-o

Helófita. Rizoma parcialmente subterrâneo, parte aérea ca. $30 \mathrm{~cm}$; entrenó inconspícuo; profilo não visto. Folha com pecíolo ca. $41,5 \times 0,8 \mathrm{~cm}$, verde, canaliculado, não geniculado apicalmente; bainha longa, ca. 36 cm compr.; lâmina 44-68 × 35-45 cm, verdes discolores, sagitada, ápice agudo, margem inteira, membranácea; divisão anterior 30-47 × 31-45 cm, nervura central aplanada, levemente saliente na face abaxial, nervuras laterais primárias 6 pares, aplanadas, nervuras interprimárias visíveis na face abaxial, nervuras laterais secundárias colocasióides; divisões posteriores 13-22 × 19-26 cm, nervuras acroscópicas 3 por lado, nervuras basioscópicas 4 por lado, nervuras basais aplanadas, levemente saliente na face abaxial, porção desnuda das nervuras basais 1,5-4 cm. Inflorescência 1 por axila foliar; pedúnculo ca. $16 \times 0,4 \mathrm{~cm}$, verde, ereto; espata constricta, com diferenciação entre lâmina e tubo, tubo 5-6,5 $\times 4 \mathrm{~cm}$, verde externamente e vináceo internamente, lâmina $13-13,5 \times 4,5-5 \mathrm{~cm}$, alva, apenas o tubo persistente; espádice heterogêneo, séssil, $13,3-15,5 \mathrm{~cm}$ compr., alvo na zona masculina e alaranjado na feminina, zona estaminada ca. $7 \times 0,7-0,8 \mathrm{~cm}$, zona estaminada estéril ca. $2,1 \times 0,5 \mathrm{~cm}$, zona pistilada ca. $1,1 \times 0,8$ $\mathrm{cm}$. Flores diclinas, aclamídeas; flor masculina ca. $2,5 \times 3 \mathrm{~mm}$, estames unidos em sinândrio, anteras poricidas; flor masculina estéril $2 \times 3,5 \mathrm{~mm}$; flor feminina ca. $2 \times 1$ $\mathrm{mm}$, ovário 4-locular, muitos óvulos por lóculo, placentação axial, região estilar da 
mesma largura do ovário, estigma papiloso. Frutos jovens alvos.

Material examinado: 23.I.2001, fl., $R$. $C$. Forzza et al. 1747 (CESJ); 6.III.2004, fl e fr., R. C. Forzza et al. 2947 (RB).

Material adicional examinado. BRASIL. MINAS GERAIS: Caratinga, Estação Biológica de Caratinga, 21.III.1994, fr., J. A. Lombardi 536 (BHCB, RB); Marliéria, Parque Estadual do Rio Doce: 22.XII.1999, fl. e fr., L. G. Temponi et al. 82 (VIC).

Xanthosoma maximiliani pode ser diferenciada das demais espécies da Reserva por possuir um rizoma parcialmente subterrâneo; lâminas foliares com as nervuras laterais secundárias anastomosantes formando uma interprimária (colocasióide) (Fig. 2o), flores femininas alaranjadas e espata fortemente constricta com a região do tubo verde externamente e vináceo internamente. A espécie tem ocorrência registrada para Pernambuco, Bahia, Rio de Janeiro, Minas Gerais e São Paulo (Lombardi \& Gonçalves 2000, Temponi 2001). Trata-se de uma espécie rara na Reserva, tendo sido encontrada em apenas um local constantemente alagado e sombreado no interior da mata.

\section{Agradecimentos}

Os autores agradecem a FAPEMIG e ao CNPq pelas bolsas concedidas e a COPASA e a PETROBRAS (convênio JBRJ/BR 610.4.025.02.3) pelo apoio financeiro, à $\mathrm{Pa}-$ trícia Carneiro L. Faria por todo apoio na execução desse trabalho, ao Sr. Luís, mateiro da Reserva, por sua ajuda durante os trabalhos de campo. Aos amigos Marcus Nadruz e Cássia Sakuragui e dois assessores anônimos pelas valiosas contribuições.

\section{REFERÊNCIAS BIBLIOGRÁFICAS}

Coelho, M. A. N. 1998. Cinco espécies novas do gênero Philodendron Schott (Araceae) para o Brasil. Boletim de Botânica da Universidade de São Paulo 17: 47-60.
Coelho, M. A. N. 2000. Philodendron Schott (Araceae): morfologia e taxonomia das espécies da Reserva Ecológica de Macaé de Cima-Nova Friburgo, Rio de Janeiro, Brasil. Rodriguésia 51(78/79): 21-68.

Coelho, M. A. N. 2004. Taxonomia das espécies de Anthurium (Araceae) seção Urospadix subseção Flavescentiviridia. Tese de Doutorado. Universidade Federal do Rio Grande do Sul, RS.

Croat, T. B. 1979. The distribution of Araceae. In: K. Larsen \& L. B. Holm-Nielson (eds.). Tropical Botany. Academic Press., London. 291-308.

Engler, A. 1905. Araceae - Pothoideae. In: Engler, A. (ed.). Das Pflanzenreich, IV 23B (heft 21). Berlin (Wilhelm Engelmann). 330p.

Gonçalves, E. G. 1999. A revised key for the genus Asterostigma C. A. Fish \& Mey. (Araceae: tribe Spathicarpeae) and a new species from Southeastern Brazil. Aroideana 22: 30-33.

Gonçalves, E. G. 2002. Sistemática e evolução da tribo Spathicarpeae (Araceae). Tese de Doutorado. Universidade de São Paulo, São Paulo, SP.

Govaerts, R.; Frodin, D. G.; Bogner, J.; Boyce, P.; Cosgriff, B.; Croat, T. B.; Gonçalves E. G.; Gayum, M.; Hay, A.; Hetterscheid, W.; Landolt E.; Mayo, S. J.; Murata, J.; Nguyen, V. D.; Sakuragui, C. M.; Singh, Y.; Thompson, S. \& Zhu, G. 2002. World checklist and bibliography of Araceae (and Acoraceae). Kew: Royal Botanic Garden. 560 p.

Holmgren, P. K.; Holmgren, N. H. \& Barnett, L .C. 1990. Index Herbariorum: The herbaria of the world. New York Botanical Garden. New York. 693p.

Lombardi, J. \& Gonçalves, M. 2000. Composição florística de dois remanes-centes de mata atlântica do sudeste de Minas Gerais, Brasil. Revista Brasileira de Botânica 23 (3): 255-282. 
Madison, M. T. 1977. A revision of Monstera (Araceae). Contribution from the Herbarium Harvard University, 207:1101.

Mayo, S. J. 1990. Problems of speciation, biogeography and systematics in some Araceae of the Brazilian atlantic forest. In: S. Watanabe et al. (eds.), Anais do II Simpósio de Ecossistemas de Costa Sul e Sudeste Brasileira, São Paulo, Brasil 2: 235-258.

Mayo, S. J. 1991. A revision of Philodendron subg. Meconostigma (Araceae). Kew
Bulletin 46(4): 601-681.

Mayo, S. J.; Bogner, J. \& Boyce, P. C. 1997. The genera of Araceae. Kew: Royal Botanic Garden. 370 p.

Oliveira-Filho, A. T. \& Fontes, M. A. L. 2000. Patterns of floristic differentiation among Atlantic forests in south-eastern Brazil and the influence of climate. Biotropica 32(4b): 793-810

Oliveira-Filho, A. T.; Tameirão-Neto, E.; Carvalho, W. A. C.; Werneck, M.; Brina, A. E.; Vidal, C. V.; Rezende, S. C. \& Pereira, J. A.A. 2005. Análise florística do compartimento arbóreo de áreas de floresta atlântica sensu lato na região das bacias do leste (Bahia, Minas Gerais, Espírito Santo e Rio de Janeiro). Rodriguésia 56(87): 185-235.

Radford, A. E; Dickison, W.C.; Massey, J.R. \& Bell, C.R. 1974. Vascular Plant Systematics. Harper \& Row, Publishers, Inc., New York. 891p.

Sakuragui, C. M. 1998. Taxonomia e filogenia das espécies de Philodendron seção Calostigma (Schott) Pfeiffer no Brasil. Tese de Doutorado. Universidade de São Paulo, São Paulo, SP. 2000. Araceae of campos rupestres from the Espinhaço Range in Minas Gerais State, Brazil. Aroideana 23: 56-81.

Temponi, L. G. 2001. Estudo taxonômico e dis-tribuição das Araceae do Parque Estadual do Rio Doce, Minas Gerais, Brasil. Dissertação de Mestrado. Universidade Federal de Viçosa, Viçosa, MG. 
